\title{
Correction to: Below-zero storage of fish to suppress loss of freshness
}

\author{
Takeya Yoshioka ${ }^{1} \cdot$ Yoshiko Konno $^{2} \cdot$ Kunihiko Konno $^{2}$
}

Published online: 4 April 2020

(c) The Author(s) 2020, corrected publication March 2020

\section{Correction to: Fisheries Science (2019) 85:601-609 https://doi.org/10.1007/s12562-019-01294-3}

The article "Below-zero storage of fish to suppress loss of freshness", written by Takeya Yoshioka, Yoshiko Konno and Kunihiko Konno was originally published electronically on the publisher's internet portal on 7 February 2019 without open access. After publication in volume [85], issue [3], page [601-609] with the author(s)' decision to opt for Open Choice the copyright of the article changed on 31st March 2020 to () The Author(s) 2020 and the article is forthwith distributed under a Creative Commons Attribution 4.0 International License (https://creativecommons.org/licenses/ by/4.0/), which permits use, sharing, adaptation, distribution and reproduction in any medium or format, as long as you give appropriate credit to the original author(s) and the source, provide a link to the Creative Commons licence, and indicate if changes were made.

\begin{abstract}
Open Access This article is licensed under a Creative Commons Attribution 4.0 International License, which permits use, sharing, adaptation, distribution and reproduction in any medium or format, as long asyou give appropriate credit to the original author(s) and the source, provide a link to the Creative Commons licence, and indicate if changes were made. The images or other third party material in this article are included in the article's Creative Commons licence, unless indicated otherwise in a credit line to the material. If material is not included in the article's Creative Commons licence and your intended use is not permitted by statutory regulation or exceeds the permitted use, you will need to obtain permission directly from the copyright holder. To view a copy of this licence, visit http://creativecommons.org/licenses/by/4.0/.
\end{abstract}

Publisher's Note Springer Nature remains neutral with regard to jurisdictional claims in published maps and institutional affiliations.

The original article can be found online at https://doi.org/10.1007/ s12562-019-01294-3.

Takeya Yoshioka

yoshioka@techakodate.or.jp

Yoshiko Konno

konnodpu@163.com

Kunihiko Konno

konno@fish.hokudai.ac.jp

1 Hokkaido Industrial Technology Center, Hakodate, Hokkaido 041-0801, Japan

2 Laboratory of Marine Food Science, Graduate School of Fisheries, Hokkaido University, Hakodate, Hokkaido 041-8611, Japan 